\title{
A Study to Assess the Effectiveness of Self Instructional Module on Knowledge Regarding Stem Cell Banking among Staff Nurses in Selected Hospitals at Bangalore
}

\author{
Malathi. P \\ Lecturer, Dept of Obstetrics \& Gynaecological Nursing, Sanjay Gandhi Institute of Trauma \& Orthopedics, \\ Byrasandra, Bangalore.
}

\begin{abstract}
Aim: Present study attempts to assess the "Effectiveness of self-instructional module on knowledge regarding stem cell banking among staff nurses in hospitals.

Methods and Material: Purposive sampling technique with the pre-experimental and post-test design was used. The sample of this study comprised 60 staff nurses who were working in the Obstetrics and Gynaecological ward. A structured knowledge questionnaire was used to collect data from the subjects. The collected data was analyzed using descriptive and inferential statistics and interpreted in terms of the objectives and hypothesis of the study.

Results: In pre-test knowledge on stem cell banking, out of 60 staff nurses, 13(22\%) had inadequate knowledge, and in post-test after implementation of SIM, 53(88\%) of subjects had adequate knowledge, and $7(12 \%)$ had moderate knowledge. The above results indicate that SIM effectively increased the ability of staff nurses on stem cell banking. The association was found between the knowledge scores of subjects with demographic variables such as gender, area of residence, and years of clinical experience, which was significant at the level of 0.05 . It is recommended that a similar study can be conducted on a larger sample to arrive at a generalization. Moreover, nurses and midwives are part of health care in all the stages of our lives. Thus, nurses must be knowledgeable and aware of recent trends in diagnosis, treatment. Education provides means by which nurses can remain up to date with current developments, maintain their competence and meet the standards of nursing practice.
\end{abstract}

Conclusion: The study's findings reveal that staff nurses' knowledge had enhanced regarding stem cell banking.

Keywords: Stem cell banking, Knowledge, Staff nurses.

\section{INTRODUCTION}

"Healing is a matter of time, but it is sometimes also a matter of opportunity"

\section{Hippocrates}

Good health is not only about being well. It is about being happy and feeling whole from a physical, mental, and spiritual point of view. The study and research of the human body and related health issues help understand how humans function and apply knowledge to improve health and prevent and cure diseases.

The umbilical cord is the essential vitalizing direct interlink between a mother and the child, always depicted as motherhood's relationship and emotional bonding, which is a beautiful experience for a woman ${ }^{1}$.

Umbilical cord blood is rich in stem cells, which are the building blocks of the blood and immune system. These biologically unique cells can develop into 
other cell types within the body. Umbilical cord blood is unique because it contains a lot of cells called hematopoietic stem cells. Cord blood banking is the practice of preserving for future use ${ }^{2}$.

In the 1970s, researchers discovered that umbilical cord blood could supply the same kinds of blood-forming (hematopoietic) stem cells as a bone marrow donor. And so, umbilical cord blood began to be collected and stored. Gluckman and his colleagues performed the first successful stem cell transplantation in 1988 when they took umbilical cord blood from a newborn and gave it to a five-year-old sibling who had Fanconi's anemia, a severe type of anemia that causes the skeletal defect. They opened a way for the subsequent development of a blood bank at New York Blood Centre; in the last sixteen years, there has been a substantial increase in the use of cord blood as an alternative stem cell source for the patients who cannot find matched bone marrow donors. Umbilical cord blood banking, an important novel medical innovation, refers to the collection and longterm storage of hematopoietic stem cells obtained from the umbilical cord from the newborn child's blood. There are two options for storing cord blood: public storage or private storage. These storage spaces are referred to as "banks",

As cord blood transplantation has become a common practice, the number of cord blood banks continued to increase worldwide. Cord life is considered the largest network of stem cell banks. India's first cord blood repository was established by reliance on life sciences, incorporated in 2001. The first strictly private cord blood bank in India is Life-cell, and it is located in Chennai. In India, there are approximately 72000 births daily, which results in discarding 72000 umbilical cords a day. The storage of stem cell-rich blood derived from these umbilical cords can prove to be the best possible insurance against lifethreatening diseases ${ }^{4}$.

Cord blood stem cells may be used in place of bone marrow or other sources of stem cells and treat numerous types of malignancies, including certain leukemias, Hodgkin's disease, and lymphoma. It has also been used to treat various anaemias, repair of heart and immune system and metabolic disorders of the children's. The majority of cord blood transplants to date have been performed in patients less than 18 years old and have been a sibling of allergenic transplants. Once considered incurable, diseases respond well to stem cell therapies and restore a quality of life to patients they thought they had lost forever ${ }^{5}$.

Moreover, nurses and midwives are part of health care in all the stages of our lives. Thus, nurses must be knowledgeable and aware of recent trends in diagnosis, treatment. Continuing education provides means by which nurses can remain up to date with current developments, maintain their competence and meet the standards of nursing practice ${ }^{6}$. Nurses are thus challenged to assimilate knowledge, develop critical thinking skills, and it is necessary to apply that knowledge into practice. Therefore, nurses need to be educated regarding the value of collecting and preserving umbilical cord blood stem cells for future use in treating illnesses.

\section{Objectives Of The Study:}

1. To assess the knowledge regarding stem cell banking among staff nurses.

2. To determine the effectiveness of selfinstructional modules on knowledge regarding stem cell banking among staff nurses.

3. To find out the association between pretest knowledge scores regarding stem cell banking with selected demographic variables of staff nurses.

\section{HYPOTHESES}

H1: There will be a significant difference between the pretest and post-test knowledge scores regarding stem cell banking among staff nurses.

H2: There will be a significant association between the pretest knowledge among the staff of nurses relating to stem 
Malathi. P. A study to assess the effectiveness of self instructional module on knowledge regarding stem cell banking among staff nurses in selected hospitals at Bangalore.

cell banking and selected sociodemographic variables.

\section{OPERATIONAL DEFINITION:}

1. Assess: It refers to evaluate the knowledge of staff nurses regarding stem cell banking.

2. Effectiveness: It refers to gain in knowledge regarding stem cell banking in staff nurses as determined by the significant difference in pre-test and post-test knowledge scores.

3. Self-instructional module: It refers to systematically developed self-learning material prepared by the researcher to impart knowledge regarding stem cell banking.

4. Knowledge: It refers to the awareness about stem cell banking in staff nurses as measured using a structured questionnaire.

5. Stem cell banking: It is a facility that stores stem cells delivered from amniotic fluid for future use. Stem cell samples in private banks are stored specifically for use by the person from whom such have been collected and banked.

6. Staff nurse: It refers to the professionally trained registered nurses and midwives who are working in selected hospitals.

7. Hospital: An institution providing medical and surgical treatment and nursing care for sick or injured people.

\section{Research Approach:}

The experimental research approach was considered to accomplish the objectives.

\section{Research Design:}

A quasi-experimental study design was chosen for the present study.

\section{Setting of the Study:}

The study was conducted at a selected hospital in Bangalore.

\section{Population:}

The study was conducted among staff nurses in a selected hospital in Bangalore.

\section{Sample and sampling technique:}

The sampling technique used for the present study was purposive sampling.

\section{Sample size:}

The sample of the study comprised 60 staff nurses. The non-probability purposive sampling method was used to draw the sample.

\section{INCLUSION CRITERIA AND EXCLUSION CRITERIA:}

\section{Inclusion criteria:-}

The study includes the staff nurses who

- Are between the ages of 25 to 40 years.

- Could understand English

- Are available during the period of data collection.

\section{Exclusion criteria:-}

This study excludes the staff nurses who are

- Who are on leave and working on the night shift during the time of data collection.

- Who are the available at the time of data collection

\section{TOOLS AND TECHNIQUES:}

Individuals who fulfilled the inclusion criteria were involved in the study with their consent. The tool used for the study comprised of a structured knowledge questionnaire, which consisted of two sections.

\section{DESCRIPTION OF THE TOOL:}

In the present study following tool was used, which consisted of two sections. SECTION A: Demographic proforma. SECTION B: Structured knowledge questionnaire was used to assess the level of knowledge. 


\section{Section A: Demographic proforma}

Investigator constructed this tool. It contained 7 items seeking information about age, gender, educational qualification, years of experience, area of residence, training courses in stem cell banking, and previous experience in assisting stem cell banking.

\section{Section B: Structured knowledge questionnaire was used to assess the level of knowledge.}

A structured knowledge questionnaire was used to assess the level of knowledge of staff nurses regarding stem cell banking. It comprises 30 multiplechoice questions on stem cell banking items, divided into 5 areas.

The total score was 30. Each favorable response carries one mark, and an unfavorable response has a zero mark. The total score was categorized as adequate (23$30)$, moderate :(15-22), inadequate(0-14). Higher scores indicated higher levels of knowledge related to stem cell banking.

Table- 1 SCORING PROCEDURE FOR ASSESSING THE KNOWLEDGE

\begin{tabular}{|l|l|}
\hline Level of knowledge & Percentage (\%) \\
\hline Inadequate & $<50 \%$ \\
\hline Moderate & $51-75 \%$ \\
\hline Adequate & $>76 \%$ \\
\hline
\end{tabular}

\section{DEVELOPMENT OF SELF}

\section{INSTRUCTIONAL MODULE (SIM)}

SIM was developed stepwise according to the planned objectives. The investigator developed the SIM for significant individuals after reviewing the literature, seeking the opinion of the experts and from personal experience. The steps in the development of SIM were:

a) Development of criteria check list

b) Preparation of the first draft of SIM

c) Establishment of content validity of SIM.

d) Preparation of the final draft of SIM.

\section{PILOT STUDY}

The pilot study is a small preliminary investigation of the same general character as the major study, which is designed to acquaint the researcher with problems that can be corrected in preparation for the large research projects or are done to provide the researcher with an opportunity to try out the procedure for collecting data The purpose of the pilot study was to find out the feasibility of the study, clarity of language of the tools, and to finalize the plan for analysis. ${ }^{51}$

The pilot study was conducted for 6 days followed by one day of teaching among 6 samples using the pretest and posttest methods. The pilot study results showed a significant difference between the mean pre-test and mean post-test knowledge level, which confirmed the teaching program was effective and reliable.

\section{METHOD OF DATA COLLECTION}

The study was conducted at Chinmaya Mission Hospital, Bangalore, for 30 days. The investigator met the staff nurses and obtained consent to assess the knowledge level, and the purpose of the study was explained to them. The sample for the study was selected by lottery method. The investigator gave a brief introduction about the tools, and a pre-test was conducted using a questionnaire.SIM was administered using visual aids and lecture cum discussion method. On the 7th day, the post-test was assessed by using the same questionnaire.

\section{RESULTS \\ SECTION 1: DESCRIPTION OF THE DEMOGRAPHIC VARIABLES.}

The result showed that the majority of the sample, i.e., $41.6 \%$ were in the age group of 25-30 years, with $87 \%$ of the samples being females, within which $78.33 \%$ of them had GNM as an educational qualification. Within the sample size, $53.3 \%$ of them had a clinical experience of 1 to 2 years, and among them, $90 \%$ lived in urban areas. Off the sample size, only $10 \%$ had attended a training course in stem cell banking, and only $8.33 \%$ of them had previous experience in assisting with stem cell banking. 
Malathi. P. A study to assess the effectiveness of self instructional module on knowledge regarding stem cell banking among staff nurses in selected hospitals at Bangalore.

Table 1. Frequency and percentage distribution of samples,

\section{$\mathrm{n}=\mathbf{6 0}$}

\begin{tabular}{|c|c|c|c|}
\hline S.No & Demographic Variables & No & $\%$ \\
\hline \multirow[t]{4}{*}{1} & \multicolumn{3}{|l|}{ Age } \\
\hline & a) $25-30 \mathrm{yrs}$ & 25 & 41.6 \\
\hline & b) 31-35yrs & 22 & 36.6 \\
\hline & c) $36-40 \mathrm{yrs}$ & 13 & 21.6 \\
\hline \multirow[t]{3}{*}{2.} & \multicolumn{3}{|l|}{ Gender } \\
\hline & a)Female & 52 & 87.0 \\
\hline & b)Male & 8 & 13.0 \\
\hline \multirow[t]{4}{*}{3.} & \multicolumn{3}{|l|}{ Educational qualification } \\
\hline & a) GNM & 47 & 78.33 \\
\hline & b) B.SC (N) & 11 & 18.33 \\
\hline & c) $\mathrm{M} . \mathrm{SC}(\mathrm{N})$ & 2 & 3.33 \\
\hline \multirow[t]{5}{*}{4.} & \multicolumn{3}{|l|}{ Years of clinical experience } \\
\hline & a)Below 1 yr & 8 & 13.33 \\
\hline & b)1-2yrs & 32 & 53.3 \\
\hline & c)2-3yrs & 10 & 16.66 \\
\hline & d) 4-5yrs & 10 & 16.66 \\
\hline \multirow[t]{3}{*}{5.} & \multicolumn{3}{|l|}{ Area of residence } \\
\hline & Urban & 54 & 90.0 \\
\hline & Rural & 6 & 10.0 \\
\hline \multirow[t]{3}{*}{6.} & \multicolumn{3}{|c|}{ Training courses in stem cell banking } \\
\hline & a) yes & 6 & 10.0 \\
\hline & b) No & 54 & 90.0 \\
\hline \multirow[t]{3}{*}{7.} & \multicolumn{3}{|c|}{ Previous experience in assisting stem cell banking } \\
\hline & a) yes & 5 & 8.33 \\
\hline & b) $\mathrm{No}$ & 55 & 91.66 \\
\hline
\end{tabular}

\section{SECTION 2:}

PART 1: ASSESSMENT OF PRE-TEST LEVEL OF KNOWLEDGE AMONG SAMPLES.

Table 2 shows the overall knowledge among staff Nurses in the selected area. The pretest shows that $13(22 \%)$ nurses had an inadequate level of knowledge, $47(78 \%)$ nurses had moderate knowledge, and none of the nurses had adequate knowledge.

Table 2

\begin{tabular}{|l|l|l|l|}
\hline \multirow{2}{*}{ Sl. No } & \multirow{2}{*}{ Level of Knowledge } & \multicolumn{2}{|l|}{ PreTest } \\
\cline { 3 - 4 } & & N & \% \\
\hline 1 & Inadequate & 13 & 22.00 \\
\hline 2 & Moderately adequate & 47 & 78.00 \\
\hline 3 & Adequate & 0 & 0.00 \\
\hline Total & & 60 & 100.0 \\
\hline
\end{tabular}

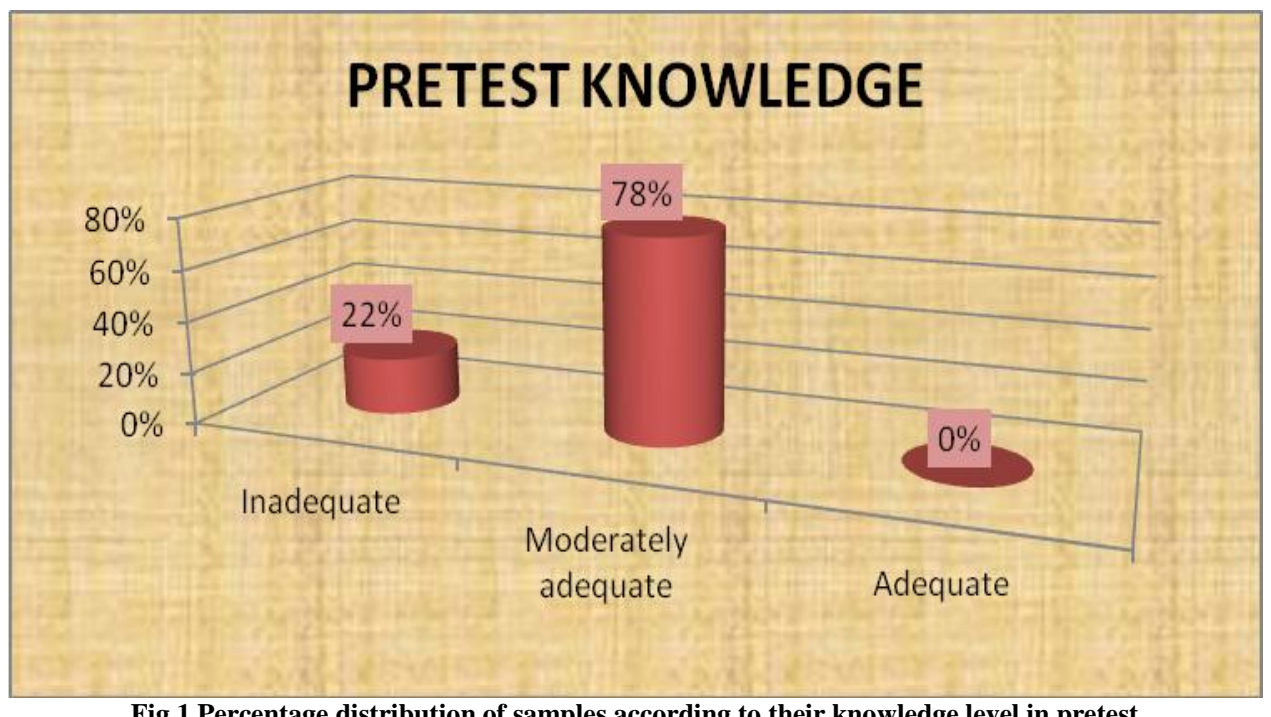

Fig.1.Percentage distribution of samples according to their knowledge level in pretest

\section{PART-2}

Table 3 shows the overall knowledge among staff Nurses in the selected area. The post-test shows that $7(12 \%)$ nurses had an inadequate level of knowledge, 53(88\%) nurses had moderate knowledge, and none of the nurses had adequate knowledge.
TABLE 3 -DISTRIBUTION OF POST-TEST LEVEL OF KNOWLEDGE REGARDING STEM CELL BANKING AMONG STAFF NURSES. $\mathrm{N}=\mathbf{6 0}$

\begin{tabular}{|l|l|l|l|}
\hline Sl. No & Level of Knowledge & \multicolumn{2}{|l|}{ Post Test } \\
\cline { 3 - 4 } & & N & \% \\
\hline 1 & Inadequate & 0 & 0.00 \\
\hline 2 & Moderately adequate & 7 & 12.0 \\
\hline 3 & Adequate & 53 & 88.0 \\
\hline
\end{tabular}




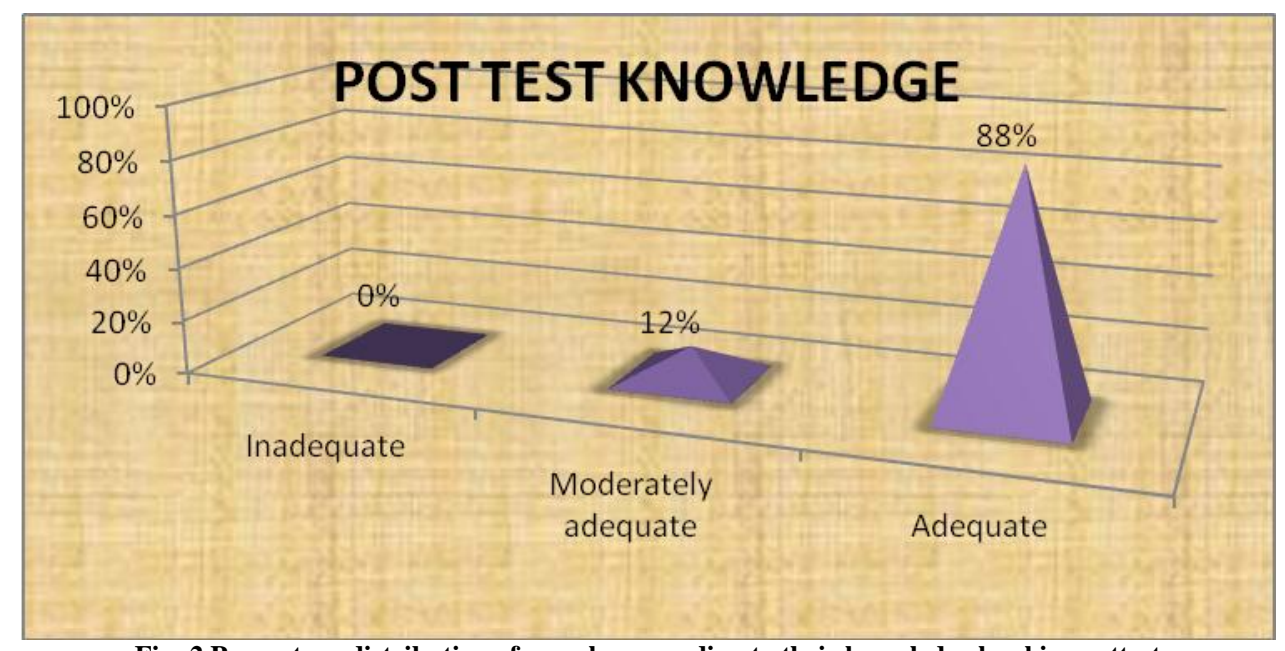

Fig :2.Percentage distribution of samples according to their knowledge level in posttest

\section{SECTION III:}

TABLE 4: COMPARISON OF PRE AND POST TEST KNOWLEDGE SCORES REGARDING STEM CELL BANKING AMONG STAFF NURSES.

\begin{tabular}{|l|l|l|l|l|l|l|}
\hline Sl. No & Observation & Mean & Mean difference & SD & Paired't'value & P value \\
\cline { 1 - 3 } 1 & Pre-Test & 11.8 & 13.7 & 1.91 & & \\
\cline { 1 - 3 } & Post-Test & 25.5 & & & $33.4 *$ SS & 0.05 \\
\hline \multicolumn{7}{|c|}{ Table value: 1.671 df $=59$} \\
SS- statistically significant
\end{tabular}

Table 4 shows the Mean and SD of pre and post-test levels of knowledge on stem cell banking among samples. In pretest knowledge, the mean is 11.8 , and in post-test, the mean is 25.5 , and the mean difference is 13.7. The standard deviation value is 1.91 . The post-test mean score
(25.5) was high when compared to the pre test mean (11.8) score of knowledge. The obtained t value (33.4) was greater than the table value at 0.05 level of significance, which shows a significant difference between the pre and post-test levels of knowledge regarding stem cell banking.

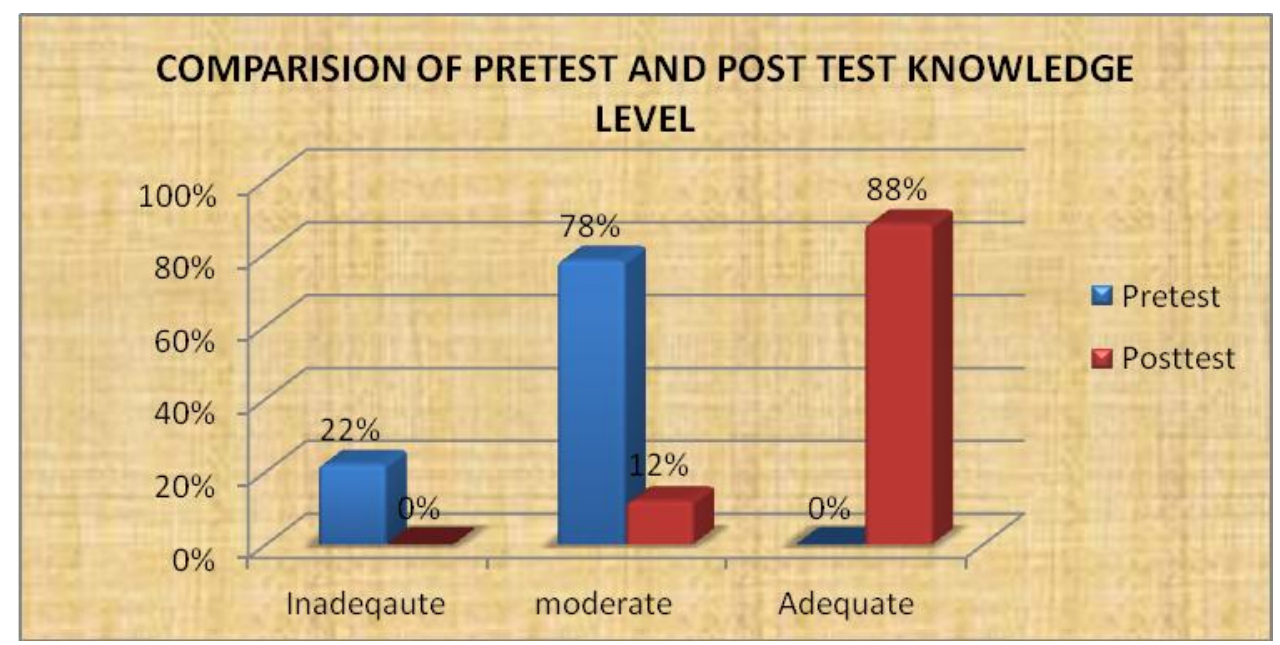

SECTION IV:

Fig. 3. Comparison of pretest and post test knowledge level on stem cell banking.
The results of the tests conducted using chi-square tests show that the association between gender and pretest knowledge scores $\left(x^{2}=23.5717\right)$, the association between years of experience and pretest knowledge scores $\left(\mathrm{x}^{2}=11.1334\right)$, and the association between the area of residence and pretest knowledge scores $\left(\mathrm{x}^{2}\right.$ $=7.9542$ ) were statistically significant.

Similarly, the results of the tests conducted using chi-square tests show that 
association between age and pretest knowledge scores $\left(\mathrm{x}^{2}=1.442\right)$, the association between education qualification and pretest knowledge scores $\left(\mathrm{x}^{2}=4.8182\right)$, the association between previous training courses attended and pretest knowledge scores $\left(\mathrm{x}^{2}=0.0982\right)$ and the association between previous experience in assisting with stem cell banking and pretest knowledge scores $\left(x^{2}=1.5087\right)$ were not statistically significant.

TABLE 5: TO FIND OUT THE ASSOCIATION BETWEEN THE PRETEST LEVEL OF KNOWLEDGE AND SELECTED DEMOGRAPHIC VARIABLES. $\mathrm{n}=60$

\begin{tabular}{|c|c|c|c|c|c|c|}
\hline \multirow{3}{*}{ Sl.No } & \multirow{3}{*}{ Demographic variables } & \multirow{3}{*}{ No } & \multirow{3}{*}{$\%$} & \multicolumn{2}{|c|}{ Level of Knowledge } & \multirow{3}{*}{ Chi-square } \\
\hline & & & & Inadequate & Moderate & \\
\hline & & & & No & No & \\
\hline \multirow[t]{4}{*}{1} & Age & & & & & \multirow[t]{4}{*}{1.442} \\
\hline & a) 25-30 years & 25 & 41.6 & 7 & 18 & \\
\hline & b) 31-35years & 22 & 36.6 & 3 & 19 & \\
\hline & c)36-40 years & 13 & 21.6 & 3 & 10 & \\
\hline \multirow[t]{3}{*}{2} & Gender & & & & & \multirow{3}{*}{$\begin{array}{l}23.5717 \\
S\end{array}$} \\
\hline & a) Female & 52 & 87 & 6 & 46 & \\
\hline & b) Male & 8 & 13 & 7 & 1 & \\
\hline \multirow[t]{4}{*}{3.} & Educational Qualification & & & & & \multirow{4}{*}{$\begin{array}{l}4.8182 \\
\text { NS }\end{array}$} \\
\hline & a) GNM & 47 & 78.33 & 8 & 39 & \\
\hline & b) B.SC(N) & 11 & 18.33 & 5 & 6 & \\
\hline & c) $\mathrm{M} . \mathrm{Sc}(\mathrm{N})$ & 2 & 3.33 & 0 & 2 & \\
\hline \multirow[t]{5}{*}{4.} & Years of clinical experience & & & & & \multirow{5}{*}{$\begin{array}{l}11.1334 \\
S\end{array}$} \\
\hline & a)Below 1 yr & 8 & 13.33 & 5 & 3 & \\
\hline & b)1-2yrs & 32 & 53.3 & 3 & 29 & \\
\hline & c)2-3yrs & 10 & 16.66 & 3 & 7 & \\
\hline & d) 4-5yrs & 10 & 16.66 & 2 & 8 & \\
\hline \multirow[t]{3}{*}{5.} & Area of residence & & & & & \multirow{3}{*}{$\begin{array}{l}7.9542 \\
S\end{array}$} \\
\hline & a) Urban & 54 & 90.0 & 9 & 45 & \\
\hline & b) Rural & 6 & 10.0 & 4 & 2 & \\
\hline \multirow[t]{3}{*}{6.} & Undergone Training courses in stem cell banking & & & & & \multirow{3}{*}{$\begin{array}{l}0.0982 \\
\text { NS }\end{array}$} \\
\hline & Yes & 6 & 10.0 & 1 & 5 & \\
\hline & No & 54 & 90.0 & 12 & 42 & \\
\hline \multirow[t]{3}{*}{7.} & Previous experience in assisting stem cell banking & & & & & \multirow{3}{*}{$\begin{array}{l}1.5087 \\
\mathrm{NS}\end{array}$} \\
\hline & a)Yes & 5 & 8.33 & 0 & 5 & \\
\hline & b)No & 55 & 91.66 & 13 & 42 & \\
\hline
\end{tabular}

\section{DISCUSSION}

Objective 1: To assess the pretest knowledge regarding stem cell banking among staff nurses.

The study revealed that none of the respondents had adequate knowledge about stem cell banking. Only 47 (78\%) had moderate knowledge and remained with inadequate knowledge, which showed that an educational program is necessary to improve knowledge about stem cell banking among the staff.

Objective 2: To determine the effectiveness of self-instructional modules on knowledge regarding stem cell banking among staff nurses.

The results analyzed post administration of SIM showed 53(88\%) respondents had adequate knowledge level, $7(12 \%)$ respondents with moderate knowledge, and none with inadequate knowledge after administration of SIM. The study results showed that post test score (mean: 39.6\%, 2.57) was higher than that of pre test score (mean: $13.23 \%, 3.88$ ).

Objective 3: To find out the association between pre test levels of knowledge regarding stem cell banking with selected demographic variables of staff nurses.

The chi-square test results showed a significant relationship between pre test scores with selected demographic variables such as gender, years of experience, and area of residence. It also found no significant relationship between age, educational qualification, and previous training courses attended. 
Malathi. P. A study to assess the effectiveness of self instructional module on knowledge regarding stem cell banking among staff nurses in selected hospitals at Bangalore.

\section{CONCLUSION}

The following conclusions can be drawn from the study findings, which are supported by evidence from the literature above:

The majority of the samples either had inadequate or moderate knowledge levels about the subject, and there was a significant increase in their knowledge level post administration of SIM. Hence it is concluded that SIM effectively improved the level of knowledge among the samples in selected hospitals in Bangalore.

\section{Recommendations:}

Based on the findings of the study, it is recommended that,

1. A similar study can be replicated with a control group.

2. A similar study can be conducted with the help of video-assisted devices.

3. This similar study can be replicated on a large sample; thereby, findings can be generalized for a large population.

4. A comparative study can be done to assess the attitude and practice of stem cell banking.

\section{Acknowledgement: None}

Conflict of Interest: None

Source of Funding: None

Ethical Approval: Approved

\section{REFERENCES}

1. Lowdermilk DL, Perry SE. Maternity and women's healthcare. 9th ed. Philadelphia: Mosby Elsevier: 2007.

2. Albano MS, Scaradavou A, Stevens CE, Rubinstein P. Extracellular DNA in cord blood plasma and applications in cord blood banking for sample identification. Transfusion. 2009 Aug;49(8):1685-91. doi: 10.1111/j.1537-2995.2009.02168.x. PMID: 19392775.

3. Rogers I, Casper RF. Umbilical cord blood stem cells. Best Pract Res Clin Obstet Gynaecol. 2004 Dec;18(6):893-908. doi: 10.1016/j.bpobgyn.2004.06.004. PMID: 15582545.

4. Varghese, S. Effectiveness of structured teaching programme on stem cell therapy among fourth-year B. SC. nursing students in selected nursing college at Mangalore. Published M. Sc. nursing thesis submitted to Rajiv Gandhi University of Health Sciences Karnataka, Bangalore. 2013; 20.

5. Abdullah, Y. Cord Blood Banking: What nurses and healthcare providers should know, American Journal of Maternal Child Nursing. 2011; 36(6): 334-350.

How to cite this article: Malathi. P. A study to assess the effectiveness of self instructional module on knowledge regarding stem cell banking among staff nurses in selected hospitals at Bangalore. Int J Health Sci Res. 2021; 11(11): 70-77. DOI: https://doi.org/10.52403/ijhsr. 20211108 